\title{
Erratum: A praxis-based approach to theological training in Cape Town
}

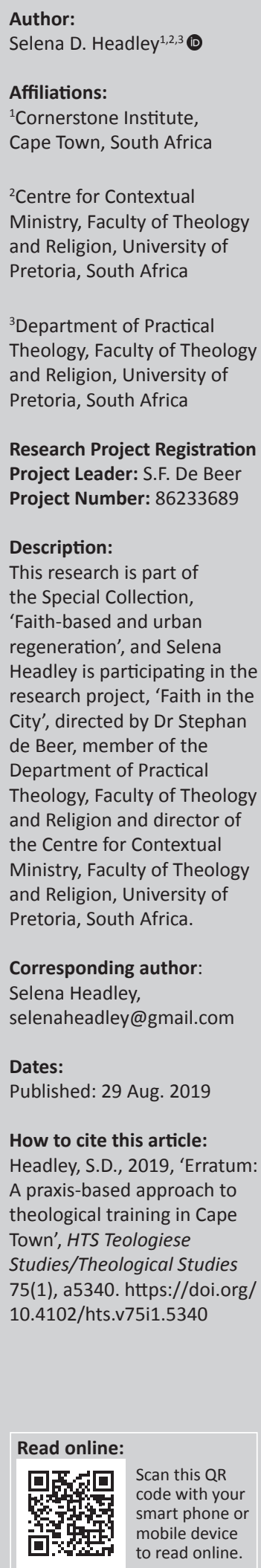

Scan this $Q R$ code with your smart phone or mobile device to read online.

In the version of this article published earlier, the conflict of interest statement was misstated. The statement is hereby updated and corrected as follows: 'The author declares that she has no financial or personal relationships which may have inappropriately influenced her in writing this article'. The publisher sincerely regrets this error and apologises for any inconvenience caused. 


\section{A praxis-based approach to theological training in Cape Town}

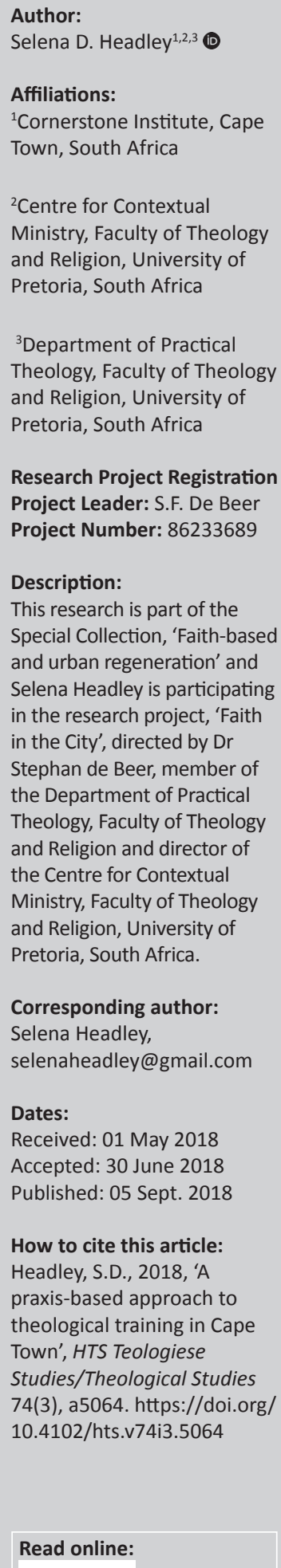

Research Project Registration Project Leader: S.F. De Beer Project Number: 86233689

\section{Description:}

This research is part of the Special Collection, 'Faith-based and urban regeneration' and Selena Headley is participating in the research project, 'Faith in the City', directed by Dr Stephan de Beer, member of the Department of Practical Theology, Faculty of Theology and Religion and director of the Centre for Contextual Ministry, Faculty of Theology and Religion, University of Pretoria, South Africa.

Corresponding author: Selena Headley, selenaheadley@gmail.com

Dates:

Received: 01 May 2018 Accepted: 30 June 2018 Published: 05 Sept. 2018

How to cite this article: Headley, S.D., 2018, 'A praxis-based approach to theological training in Cape Town', HTS Teologiese Studies/Theological Studies 74(3), a5064. https://doi.org/ 10.4102/hts.v74i3.5064

Read online:

A training programme that employs the use of the pastoral cycle, leading practitioners into a praxis-based approach towards urban transformation, may be shifting the focus of some faithbased practitioners, sparking change in communities. In 2016, a diverse group of individuals engaged in a 10-month leadership training programme centred around the pedagogical framework of the praxis cycle as a method of engagement in their diverse contexts across the city. This article will consider the ways in which the introduction of a praxis-based approach led participants on a journey of self-reflection, social analysis, prophetic imagination and planning for social transformation. Consideration will be given to the ways in which the shared journey through the praxis cycle influenced the practical knowledge and actions of the participants. This article will explore the employment of a praxis-based approach to theological training among a group of faith-based practitioners in Cape Town.

\section{The challenge of South African cities}

South African cities are facing enormous challenges, and Cape Town is no exception. The inclusive cities chapter in the State of South African Cities Report 2016 (SACR 2016) (Karuri-Sebina \& Mammon 2016:142,158) indicates Cape Town continues to be one of the most unequal cites in the world and on the continent. For Christian religious practitioners who focus their efforts towards those at the margins of social and economic life in the city, serious doubts remain about who has a right to the city. The SACR 2016 concludes the discussion about inclusive cities, with a strong statement highlighting systemic, unequal social and spatial access:

\begin{abstract}
Urban social and spatial justice will not be achieved for the large majority in South African cities unless the ongoing urban migration is into well-serviced or better located areas, including the previously white or middle-income suburbs, as a result of upward mobility and being able to afford to live there. This implies that the collective and universal aspects of achieving the 'right to the city' have been ignored in favour of citizens who can afford to buy their right to the city. In other words, South African cities have not allowed the social functions of the city and the use of public resources, such as public land, transport and facilities, to achieve urban inclusion at city-wide scale. (Karuri-Sebina \& Mammon 2016:157)
\end{abstract}

Through theological training, there is an opportunity to prepare workers who will seek the welfare of the city by connecting with those who continue to be excluded from the economic and political decision-making tables. It is clear that more work needs to be done to include the voice of the marginalised urban poor in the city. Görgens and Van Donk (2012) captured the sentiments of underprivileged Capetonian participants in a communiqué that resulted from several 'right to the city' dialogues:

We are not treated as though we are important or that we have a role to play in the future of our cities. Instead we are kept on the edges of the cities, far away from the jobs, middle-class neighbourhoods and high quality services. When the government delivers services into our neighbourhoods, we are treated like objects or nuisances rather than as equal citizens and potential partners. We need a change in attitude and approach to make us all feel like we have a right to South African cities. We need to change it from 'A City That Works for You' to 'A City That Works with You'2 (Isandla Institute 2011b:1; original emphasis). (Görgens \& Van Donk 2012:10) ${ }^{1}$

There are two faces to the city of Cape Town. The world knows the face of the fun, beautiful 'world class' city with Table Mountain, great restaurants and beautiful beaches (Bickford-Smith 2010:102-109; Fu \& Murray 2014:843-845). The unseen face of the city is where a significant portion of the city's population resides, in marginalised communities, overcrowded townships and underserviced informal settlements. Turok and Borel-Saladin (2018:776) cited Statistics

1.Author's footnote: " "The city that works for you" is the motto of the City of Cape Town' (Görgens \& van Donk 2012:21). 
South Africa's 2011 census indicating 20\% of residents of Cape Town lived in informal dwellings. A recent Statistics South Africa report (2017:90) documents an increase in household poverty nationally between 2011 and 2015, estimating one in three households or $29.2 \%$ in urban areas are living below the upper bound poverty line (UBPL). ${ }^{2}$ People often struggle to meet basic needs such as access to food, water, sanitation and housing, with limited employment options and poor educational prospects:

Despite racial integration in middle- to higher-income urban suburbs, the majority of poor black households continue to live in peripheral, poorly located areas with insufficient access to opportunities and resources, and long expensive commutes to areas of employment. Unemployment is unacceptably high, resulting in widespread poverty and growing inequality. (KaruriSebina et al. 2016:50)

The poverty trap, entwined with multiple layers of disadvantage, arises from the interconnected web of systems that suppress opportunities and create hardship from the intersection of multiple deficiencies. The SACR 2016 chapter 'Inclusive Cities: The Pursuit of Urban Social and Spatial Freedoms for All' (Karuri-Sebina \& Mammon 2016:128) begins with the story of an individual who embodies a web of disadvantage. The narrative, based on a true story, is presented as a sketch of the hardships faced by many dwelling in townships. Seventeen-year-old Andile resides in a shack in an informal settlement within Khayelitsha, where three adults and four children live on a combined income of less than R4500 per month. Partway through Grade 11 he is unjustly dismissed from high school when he is wrongly linked to gang activity in the school. His domestic worker mother and family members lacked the means to challenge the school expulsion, although he was a promising student. Experiencing social, spatial and economic exclusion, Andile remains at home with little prospect of completing his education or finding employment (Karuri-Sebina \& Mammon 2016:128).

Through the story of an individual like Andile, the struggle for survival is brought into focus, mirroring the experiences of the majority of the urban poor in the face of prevailing bifurcated South African cities. Karuri-Sebina and Mammon (2016:128158) detail urban challenges such as social vulnerability, access to basic services, urban migration, public transport networks, racial and class integration, urban inequality, crime, collective violence and government interventions in South African cities. The authors conclude that economic exclusion remains a barrier because:

South African cities have not allowed the social functions of the city and the use of public resources, such as public land, transport and facilities, to achieve urban inclusion at city-wide scale. (Karuri-Sebina \& Mammon 2016:157)

The South African cities barometer indicates that access to urban resources has improved, [sic] However, South African cities are still largely benefiting those who can afford to 'buy' their rights and freedom to the city, while thousands like Andile and his family (and many migrants) are still socially, spatially, culturally and economically excluded. (Karuri-Sebina \& Mammon 2016:157)

Theological education and training is needed that will prepare Christian religious practitioners with the tools, understanding and capacities to connect, accompany and advocate for those most affected by urban inequalities. Practitioners may want to respond by participating in initiatives to uplift the plight of the city's poor, but they often lack the kind of training that leads to deep encounters with urban structural challenges. Where inclusion and access are a daily battle for marginalised communities, churches and faith-based initiatives require people who have the sociological and theological frameworks to work towards long-term change, respecting the right of all to live a humanising, dignified existence in the city.

\section{The need for theological training that is responsive to the context}

Globally, practices related to theological education or Christian education for the purpose of training Christian ministers or practitioners have had limited engagements with the realities of urban challenges. At its worst, theological education has mirrored Western hegemonic thinking and practices, which have in times past allowed the theological enterprise to fall prey to the service of oppressive states and dehumanising worldviews such as apartheid and colonialism (Vellem 2017:2). Often voices of black, feminist or liberation theologians that could address imbalances have been marginalised, never being allowed to hold equal weight at the academic table. Naidoo (2016:1-2) points to 'the legacy of colonial forms of theological education' and the contemporary effects of globalisation as alienating forces within theological curriculum in Africa. Not long ago, Maluleke (2006) noted:

... even today, it is still possible to attain a diploma or a basic degree in theology within (South) Africa and to do so without having ever read any work by an African. (p. 66)

Dominant theories, fuelled by staid forms of pedagogy, have been undergirded by standardised empirical and rational ways of knowing, supressing alternative ways of knowing and experiencing the world. As Naidoo (2016) suggests:

The dominant Eurocentric universality claim must continue to be challenged and dismantled in order to make room for other theological traditions to become included as partners in an authentic and mutual dialogue. (p. 2)

Twenty-four years after democratic rule was inaugurated, educational models remain largely unchanged, failing to establish liberative practices to stimulate community transformation. Academic programmes are needed that will shape people's minds, hearts and actions in ways that create a more humane society while endorsing marginalised perspectives and voices:

In the African context, the prevailing paradigm of theological education and even current proposals for its reform exist within 
a Western frame of reference which reflects the tension between African communal culture and tendencies towards isolationism, individualism and competition. (Naidoo 2012:67)

In South Africa, the hard-fought struggle for equality for the majority of the population, following centuries of colonial rule and decades of oppression under apartheid, calls for liberative academic practices to create a generation of theological practitioners who are equipped to build a more inclusive and just society.

The rapid rate of African urbanisation has also created new demands for Christian workers to exercise transformative thinking and action. 'Africa has the highest urbanisation rate in the world' (SACN 2016:12). Perhaps the enterprise of theological education must take into account what we want students to become in light of demanding contexts, in order to reconsider our educational practices. If we can break away from dominant narratives long enough to ask, what do we want students to become, fresh possibilities can open up to explore and employ educational practices that shape transformative thinkers. How could theological education unlock critical thinking, leading to out-of-thebox thinking about urban challenges? Adaptive, generative models of theological education are needed to stimulate imaginations to envision more humane cities in Africa.

Reflecting on theological education at the University of Pretoria, De Beer (2012) supports the comprehensive incorporation of urban challenges within the curricula:

The theological faculty has to consider preparing students more deliberately for the range of urban contexts in which they will find themselves ministering, ranging from sprawling townships and informal settlements to wealthy security estates; from decaying inner cities to well-established urban suburbs; from the streets to the board-rooms; each offering unique contexts of urban change and challenge. (p. 273)

Cape Town is a post-apartheid city that continues to be a place where residents on the margins must fight for their right to the city. Oldfield and Wafer (2014:123-126) document the numerous ways individuals and communities are excluded from the promise of democratic participation and forced to struggle for basic needs such as housing. In South African cities the allocation of resources, and even research initiatives, are often weighted towards well-resourced residents. For example, Siyongwana and Heijne (2014) note the dearth of attention paid to townships in a national crime survey, which only cited one township community:

Nevertheless, national victimization surveys failed to reflect an in-depth picture of communities in townships where contact crime (crime against a person) ${ }^{1}$ and violent crime rates are the highest. To date the only empirical study of crime and insecurity carried out in South Africa was in the township of Khayelitsha in Cape Town. (p. 129) 3

3.Authors' footnote: 'TThe South African Police Service, Department of Police defines the following categories as contact crimes (crime a "Comm a person): "Assault with the intent to inflict grievous bodily harm," "Common assault" "Robsary w the intent to inflict grievous bodily harm," "Common Assault," "Robbery with aggravation circumstances," "Common Robbery," "Total sexual crimes," "Murder" and "Attempted murder"'.
The theological education called for here is the kind of vocational preparation that can assist students to interact with the complex of urban challenges faced by marginalised individuals and communities. Such a focus can prepare practitioners to adequately participate and contribute to the well-being of South African cities, which have faced tremendous upheaval and change in the past 25 years.

Reimagined epistemologies and pedagogies are needed to unlock potential and invigorate the spirituality of practitioners in ways that will equip them to revitalise communities of faith, while energising and mobilising the marginalised in African cities such as Cape Town. The field of Practical Theology holds the possibility of equipping students to become urban practitioners who concretely engage with the lived realities of communities. A theological training model offered through the Centre for Contextual Ministry (CCM) at the University of Pretoria offers fresh possibilities to root theological education in urban realities through engagement in a praxis-based pedagogical approach.

\section{A personal encounter with the praxis-based approach}

During April 2016, I embarked on a journey with 12 other faith-based practitioners facilitated by practical theologian Stephan De Beer, inducting the first Cape Town-based cohort working through the Leadership in Urban Transformation (LUT) course offered through the CCM. The LUT course is designed to equip urban practitioners from multiple environments to interface deeply with urban challenges. This happens through intensive exposure to knowledge, values, skills and practical engagement with local urban contexts. Although I had been involved in faith-based development efforts, church-based training and higher education spaces for over 20 years, I had never encountered such a transformative space for teaching and learning. Part of the richness of the journey came from the gathering of diverse practitioners - across race, class and gender - coming from varied contexts throughout the city of Cape Town. The unique methodology of the course, rooted in a contextual approach framed through the 'pastoral-praxis' circle or 'praxis cycle', revolutionised my thinking about ministry training and theological education. ${ }^{4}$

Walking through the praxis cycle with a small group of fellow practitioners opened up new vistas, revealing new contours and contestations within the city. The process fuelled all kinds of questions about inclusion and exclusion of marginalised peoples and communities. I began to consider the place of restrictive versus liberating structures in traditional institutions of teaching and learning, including my role as a lecturer in a private institution of higher learning. I began to wonder what it would look like for theorising, teaching and learning to take place from

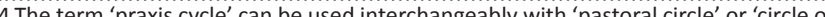
prais', popularised by Holland and Henriot (19837-8) to describe an ong oing spira praxis', popularised by Holland and Heniot (1983:7-8) to describe an ongoing spiral of action and reflection. Karecki (2005.139) uses the term 'cycle' as it 'connotes a more dynamic movement within a process that is not only used once, but over and over as students do missiology in the context of their local situation'. 
below in the midst of the chaos of the city, rooted in the contexts where people live and work.

There was also something deeply personal about this approach, which integrated spirituality and a holistic worldview. The emancipatory nature of the praxis-cycle framework created space for theological inquiry in tension with self-reflection, social analysis, spiritual formation and theological reflection, leading to new actions. The generative nature of practical inquiry, firmly rooted within specific communities, provided participants with fresh insights and responses to local challenges.

Engagement with a praxis-based approach brought a deep level of discomfort with the ways I had been engaging in ministry in the context of Cape Town. The reflective and unsettling process led me to re-examine my ministry model, teaching practice, community engagement and lifestyle choices. The process forced deep consideration of the pervasive role of systemic injustice in perpetuating poverty and marginalisation for many of the residents of the city. Reflecting deeply on my place in the city, my vision for my life's work took on different dimensions. This refocusing was influenced by the experiential learning induced by the praxisbased approach and the learning community that developed among the group of urban practitioners over the 10-month duration of the course. LUT provided a fresh orientation towards stimulating transformation 'from below', bearing in mind the need for collective approaches to fuel change in a city entwined with structural injustice.

\section{The praxis cycle for urban theological engagement}

In Social Analysis: Linking Faith and Justice, Joe Holland and Peter Henriot (1983) present a model of the 'pastoral circle' or 'circle of praxis' for faith communities to engage deeply in discerning the social reality of their context in order to develop just plans for action. The strength of the model is the way it helps participants unpack the 'social, moral, and ethical implications' of particular social issues in order to affect social change grounded in Christian faith and values (Trokan 1997:148). The LUT course uses the praxis cycle model to lead participants through a protracted process of study and engagement within the various urban locations where they are based.

Holland and Henriot (1983:7-8) describe the circle of praxis as a sequence of four related movements of action and reflection: '(1) insertion, (2) social analysis, (3) theological reflection, and (4) pastoral planning', placing experience in the middle. Holland and Henriot (1983:8) credit the term 'praxis', seen as 'reflection and action directed at the structures to be transformed', to Paulo Freire and his seminal work Pedagogy of the Oppressed (2000:126).

The LUT course was designed around the praxis cycle, which provides a framework to not only examine one's own life and way of being but to analyse and reflect on how to discern the diverse positive and negative factors that make up the complexity of cities. In LUT, the in-depth movement through the cycle happens in a small community of fellow learners undergirded by a lived experience of spirituality. The praxisbased approach provides a pedagogical style that leads practitioners to consider the whole of life and the social systems that are interwoven in urban ministry contexts. Holland and Henriot (1983), Freire (2000) and Groome (1991; 1999) provide a praxis-based framework that is a transformative paradigm. This model is responsive through an ongoing spiral of deliberation and engagement as it is applied to the process of theological education. In the tradition of Freire (2000:78-93), LUT promotes an educational process rooted in problem-posing and dialogue, helping to awaken the critical consciousness of participants.

\section{Leadership in urban transformation in Cape Town - A praxis-based journey}

LUT was hosted by the Warehouse, ${ }^{5}$ a faith-based organisation that was established in 2002 to assist churches in Cape Town to serve marginalised communities through training and engagement to act against poverty, injustice and racial-social divisions. Some of the 13 participants who enrolled in the LUT course knew each other prior to joining the course, but all shared the hope of being agents of change in the city. The course was designed in a block release style, where participants would meet for four consecutive days, five times over a 10-month period. Throughout the duration of the course, participants were expected to engage in reading, reflection and writing during the intervals of up to 7 weeks between contact sessions. Each movement of the praxis cycle led to the production of a formative essay, integrating the experiences and study of each step of the praxis cycle. The course concluded with a summative presentation by each participant on his or her plan for action followed by a final paper synthesising her or his engagement with the praxis cycle over the year.

A key methodology in the teaching process was the exposure of participants to specialists reflecting multiple disciplines such as academics, community members, urban geographers, sociologists, systematic theologians, city planners and community activists - to broaden the consideration of urban undercurrents. Koopman (2009) speaks of the significance of a transdisciplinary approach in the development of public theology:

Transdisciplinarity refers to the attempt to solve complex public problems from the local to global levels by drinking from the diversity of knowledge, insights and perspectives of various academic disciplines, practitioners and members of various sectors of public life. The expertise of every discipline and sector is respected, but disciplinary and sectorial boundaries are destabilised. Dualisms and even incommensuralibilities between, for instance, the secular and religious, the human and 5.Information about the Warehouse can be found at http:///www.warehouse.org.za 
the natural sciences are challenged. The goal of the joint reflection is not only to understand challenges better, but to transform society and to enhance justice and dignity for all. (p. 420)

Transdisciplinarity was also evident between the diverse group of participants, along with the interplay and complexities of race, class and gender that were also weaved throughout the course content. The diversity of the participants made for rich and challenging interaction throughout the sessions. The LUT course was infused with opportunities to hear the voices and stories of those most affected by the challenges of urbanisation. At the same time participants reflected on their own disciplines, stories and communities.

The first LUT contact week framed the learning experience, grounded in the context of the city and an ethos of Christian spirituality. Participants were introduced to the praxis cycle, framing theological engagement within the city along with the opportunity to understand one another's contextual immersions. 'This is the moment of contact, the anecdotal, the asking of what is happening' (Henriot 2005:17). Osmer (2008:sec. 92) suggests the descriptive-empirical task of practical theological interpretation is to ask, what is going on, to gather information to discern patterns and dynamics from particular situations or contexts. Through LUT participants were given tools to reflect on their unique position and context in the city.

A formative experience during Week 1 was the mobile classroom, consisting of a day of exposure to urban realities. Traveling from one end of the city to the other, visiting contested spaces, listening to the voices of those at the margins was both enlightening and disturbing. Graham and Lowe (2009:49-66) speak of the value of engendering a 'theology of space and place':

Once we are conscious of the significance of space and place for understanding some of the underlying dynamics of urban life, then we can become more conscious of how to shift from simply exercising the givenness or 'everdayness' of inhabiting urban space, towards a more considered analysis of what it might mean. (Graham \& Lowe 2009:51)

The day-long multisite journey included opportunities to listen to individuals who were entrenched in struggles for basic needs, security and dignity throughout Cape Town. The wide range of exposure - from a land claim site in Bishop's Court to informal settlements in Khayelitsha plunged participants into wrestling with the forces at work in an economically, socially and racially divided city. This was a formative experience as participants were brought face to face with the relationship between poverty and vulnerability versus access to resources and well-being in Cape Town.

The second contact week assisted participants to employ critical readings of the city engaging in social analysis, the second movement of the praxis cycle. Holland and Henriot (1983) promote the value of social analysis as a means to help individuals and groups grasp the big picture of what is happening in communities:

Using social analysis, we can respond to that larger picture in a more systematic fashion. By dealing with the whole, rather than with detached parts, we are able to move beyond 'issue orientation', or a primarily pragmatic approach, towards a holistic or systemic approach. (p. 10)

Week 2 helped urban practitioners gain a deeper understanding of how past wounds, prevalent worldviews and present social systems shape the dynamics of community challenges. Participants were encouraged to consider the interconnectedness of individuals, groups and institutions in relation to their social concern, examining cause, consequences and linkages among the identified actors (Holland \& Henriot 1983:8). This facilitated a multilayered exegesis of the city in relation to each participant's place of immersion.

The third contact week followed the period of critical reading of the context in relation to one's ministry focus with theological reflection. Participants were led into theological reflection to develop a hopeful imagination for urban alternatives in relation to biblical texts. 'The Word of God brought to bear upon the situation raises new questions, suggest new insights, and opens new responses' (Holland \& Henriot 1983:9). Brueggemann (2001) promulgates the cultivation of a 'prophetic imagination' in relation to prophetic writings to engage with present realities:

When one considers the issues of liberation and exploitation on the ground, then the intimate contact between biblical texts of a prophetic sort and matters of social justice, social interest, and social criticism seem to me to be incontrovertible. (2001:sec.73)

Given the freedom to reflect theologically about their contextual challenges in dialogue with biblical texts, participants began to reimagine renewed possibilities for broken communities and contested spaces in their neighbourhoods.

During the fourth contact week, participants were further exposed to transformational urban development, preparing them to dive into pastoral planning for their local areas. Based on the learnings from the previous months, they were given the opportunity to integrate all they had absorbed towards the construction of transformative plans for action towards urban development. Karecki (2005), who adapted the pastoral cycle to teach several courses in Missiology at the University of South Africa, highlights a pedagogical task of theological education in the application of the praxis cycle:

Such an approach provides people with the tools to understand what is happening in the depths of their being, to discern the events shaping the society in which they live and their response in differing contexts that have been shaped by historical events. (p. 138)

At this stage of the course, the group was prepared to design action plans, bearing in mind that 'poverty cannot be effectively responded to only through charity but must include a commitment to justice' (Henriot 2005:18). Rooted in fresh comprehension of social dynamics and prophetic 
imagination towards urban challenges, participants focused on researched priorities to formulate strategic plans for action.

Contact Week 5 was the culmination of 10 months of community-based interaction, study, reflection and engagement around their primary social concern within a learning community of urban practitioners. Karecki (2005) cites Groome's (1987:3) description of 'doing theology on our feet' as the way the praxis-based approach allows educators to facilitate the process of growthin knowledgeand understanding:

Learning becomes transformative as students grapple with their assumptions about faith and life and begin to understand their experience through a process of critical theological reflection on their own faith history as rooted in a particular context. (p. 138)

This kind of critical theological reflection surfaced as each participant was given the opportunity to present their plan of action to the group. Participants demonstrated how they proposed to tackle their social challenge, connecting their insertion, social analysis, prophetic imagination and pastoral plan.

The synthesis of the learning that emerged from the presentation process was rich, integrated and inventive after many months of reflection and action. Participants created ambitious and imaginative ways to stimulate urban transformation in their communities. The collective learning experience resulted in fresh collaborations and synergies, while stimulating rich feedback and support of the proposed plans for action among the participants. The presentation formed the basis for the final integrative essay, allowing participants to once again ground their learning and prepare to re-engage in their context with new plans for action and tools to continue the spiral of engagement with the praxis cycle. Inventive long-term plans, dreams and visions emerged with the potential to reshape the ministry focus of participants and incubate transformative plans of action for communities in the city. A rich outcome of the year-long journey was the formation of a 'community of practice' among the participants (Wenger-Trayner \& Wenger-Trayner 2015). ${ }^{6}$

\section{Generative lens for theological education and urban engagement}

Parker Palmer (1993) in To Know as We Are Known suggests locating and understanding oneself can be central to teaching and learning in humanising ways, which defy conventional approaches to education. As an LUT participant, exposure to the praxis-based approach opened up an alternative learning experience and connected me to experience my place in the city as part of a learning community towards knowing and being known (Palmer 1993:35). Engaging in the praxis cycle contributed to my level of self-awareness, enabling me to recognise 'all I don't know' about the work of teaching and learning in the areas of community development and social transformation in the context of African cities.

At the same time, I gained recognition of the essential place of empowering students, individuals and communities to engage deeply in the process of personal and societal analysis in order to move towards transformative practices. Moving beyond modalities of service delivery and community development, the central role of sharpening the ability of student-practitioners to engage deeply in the social context emerged as a central framing approach to teaching and learning. Through analysing the social structures of the city within a community of faithbased practitioners, I discovered deeper expressions of my place as an aspiring activist-academic and community development practitioner. Besides continuing to work through the praxis cycle in the academy and community, collaboration is ongoing with the CCM and Warehouse staff. Working together we have facilitated a pathway to see a second cohort complete the LUT course in 2017, with ten more practitioners currently enrolled in the course for 2018.

Each LUT participant experiences unique discoveries through engagement in the praxis-based approach in connection to social challenges in her or his place in the city of Cape Town. Theological education seldom focuses on generative approaches to prepare spiritual leaders who will lead congregations bombarded with urban challenges. The use of a praxis-based approach provided a fresh framework to refocus diaconal ministry from charitable efforts characterised by service delivery and community projects towards necessary deeper reflection on systemic injustice, creating practical pathways to societal transformation.

For many of the LUT participants, substantial engagement with the pedagogical framework of the praxis cycle shifted paradigms to embody new plans of action in their ministry contexts. In the year following completion of the course, the 'prophetic imaginings' of the group played out in tangible ways that continue to unfold.

The course connected two practitioners to join forces in building community and raising awareness to structural injustice among a small community in Khayelitsha. Other programme leaders moved towards infusing de-colonial thinking in their mentoring of afterschool programme leaders across the city. Some took the study of spatial injustice into suburban congregations, using the praxis cycle as a way to help members wrestle with the implications of land ownership and use of church property.

The community of practice forged among LUT participants in the Warehouse space has led to enriching ongoing connections. The links between the participants, the academy, the church and civil society continue to grow fresh collaborations. The communal learning process embedded in the employment of the pastoral cycle stimulates movements between one's own practice, community engagement, theological frameworks, critical analysis and networks of community-based participation. 
Working through the praxis cycle with a diverse group of practitioners led to the discovery of a larger framework to wrestle with new ways to seek the well-being and wholeness of shalom in the city of Cape Town. Transformative learning developed when participants could integrate theory and practice embedded in the context of the lived reality of communities in the city. For LUT participants, the pedagogical approach opened up fresh exploration of the connection between theory and practice solidified in a praxis-based approach to theological education.

The praxis-based approach also led participants on a shared journey of self-reflection, social analysis, prophetic imagination and planning for social transformation. The shared journey influenced the practical knowledge and actions of the participants, opening up fresh imagination in challenging urban places and creating spaces for innovation and community-based teaching and learning. De Beer (2012) resonates the call for liberating theological education that can foster the development of urban practitioners:

Responsible pastoral praxis requires sensitive, wise and discerning urban readers who would reflect critically on various texts and contexts, on both bible and city. Theological education has the challenge of fostering a new generation of urbanists, that is, reflective urban practitioners. (p. 260)

The journey of LUT participants may provide further insight to discovery training approaches that free Christian practitioners to embrace their immersions in the city based on the understanding that transformative learning and actions come from deep reflection and integration within urban contexts. By tracing the transformational ways of learning and being embedded in the pedagogical framework of the praxis-based approach, new understandings may emerge to equip urban practitioners. Such fresh methods could lead to innovative designs for robust theological curricula and action-oriented communities of practice, where creativity can be unlocked to tackle African urban realities rooted in holistic theological praxis.

\section{Acknowledgements Competing interests}

The author declares that he has no financial or personal relationships which may have inappropriately influenced him in writing this article.

\section{References}

Bickford-Smith, V., 2010, 'The fairest cape of them all? Cape Town in cinematic imagination', International Journal of Urban and Regional Research 34(1), 92-114. https://doi.org/10.1111/j.1468-2427.2009.00902.x

Brueggemann, W., 2001, Prophetic imagination: Revised edition, 2nd edn., Fortress Press, Minneapolis, MN.<kindle edition>

De Beer, S., 2012, 'Urban South Africa: An opportunity for liberating theological education', Missionalia: Southern African Journal of Missiology 40(3), 251-277. https://doi.org/10.7832/40-3-32

Freire, P., 2000, Pedagogy of the oppressed, 30th Anniversary edn., Continuum, New York.
Fu, A.S. \& Murray, M.J., 2014, 'Glorified fantasies and masterpieces of deception on importing Las Vegas into the "New South Africa"', International Journal of Urban and Regional Research 38(3), 843-863. https://doi.org/10.1111/1468-2427.12006

Görgens, T. \& van Donk, M., 2012, 'Exploring the potential of the "Right to the City" to integrate the vision and practice of civil society in the struggle for the socio-spatial transformation of South African cities', in Strategies to overcome poverty and inequality: Towards Carnegie III, pp. 21, Isandla Institute, Cape Town.

Graham, E.L. \& Lowe, S., 2009, What makes a good city? Public theology and the urban church, Darton, Longman and Todd, London.

Groome, T.H., 1991, Sharing faith: A comprehensive approach to religious education and pastoral ministry the way of shared praxis, Wipf and Stock Publishers, Eugene, OR

Groome, T.H., 1999, Christian religious education: Sharing our story and vision, 1st edn., Jossey-Bass, San Francisco, CA.

Henriot, P., 2005, 'Social discernment and the pastoral circle', in F. Wijsen, R. Mejia \& P. Henriot (eds.), The pastoral circle revisited: A critical quest for truth and transformation, pp. 15-26, Orbis Books, Maryknoll, NY.

Holland, J. \& Henriot, P., 1983, Social analysis: Linking faith and justice, Revised and Enlarged edn., Orbis Books, Maryknoll, NY.

Karecki, M., 2005, 'Teaching missiology in context: Adaptions of the pastoral circle', in F. Wijsen, P. Henriot \& R. Mejia (eds.), The pastoral circle revisited: A critical quest for truth and transformation, pp. 137-150, Orbis Books, Maryknoll, NY.

Karuri-Sebina, G. \& Mammon, N., 2016, 'Inclusive cities: The pursuit of urban socia and spatial freedoms for all', in K. Davidson (ed.), State of South African cities report 2016, pp. 124-159, South African Cities Network, Johannesburg, viewed 16 March 2018, from http://www.socr.co.za/wp-content/uploads/2016/06/SoCR16MainReport_04Inclusive.pdf

Karuri-Sebina, G., Joseph, S.-L., Bickford, G. \& Magni, P., 2016, 'The spatia transformations of South African cities: From abstract concepts to meaning and means', in K. Davidson (ed.), State of South African cities report 2016, pp. 44-81, South African Cities Network, Johannesburg, viewed 16 March 2018, from http://www.socr.co.za/wp-content/uploads/2016/06/SoCR16-MainReport_ 02Spatial.pdf

Koopman, N.N., 2009, 'For God so loved the world ... Some contours for public theology in South Africa', NGTT / Nederduitse Gereformeerde Teologiese Tydskrif 50(3\&4), 409-426, viewed 24 October 2017, from http://ojs.reformedjournals. co.za/index.php/ngtt/article/view/1079

Maluleke, T.S., 2006, 'The Africanization of theological education: Does theological education equip you to help your sister?', in E.P. Antonio (ed.), Inculturation and postcolonial discourse in African theology, pp. 61-76, Peter Lang Publishing Inc., New York, NY.

Naidoo, M., 2012, 'Approaches to ministerial formation in theological education in South Africa', Theologia Viatorium 36(1), 50-75, viewed 25 August 2017, from http://uir.unisa.ac.za/handle/10500/19830

Naidoo, M., 2016, 'Overcoming alienation in Africanising theological education', HTS Theological Studies 72(1), Art. \#3062, 1-8. https://doi.org/10.4102/hts.v72i1.3062

Oldfield, S. \& Wafer, A., 2014, 'Beyond participation or resistance: Contesting participation in Cape Town', in N. Kotze, R. Donaldson \& G. Visser (eds.), Life in a changing urban landscape: Proceedings of the IGU Urban Geography Commission (Urban challenges in a complex world), pp. 121-128, University of Johannesburg, (Urban challenges in a complex world), pp. 121-128, University of Johannesburg, Johannesburg, viewed 22 March 2018, from https://www.unil.ch/igu-urban/
files/live/sites/igu-urban/files/Life $\% 20$ in $\% 20 a \% 20$ changing $\% 20$ urban $\%$ files/live/sites/
20space.pdf

Osmer, R.R., 2008, Practical theology: An introduction, William B. Eerdmans Pub. Co. Grand Rapids, MI, <kindle edition>.

Palmer, P.J., 1993, To know as we are known: Education as a spiritual journey, HarperSanFrancisco, New York.

SACN, 2016, State of South African cities report 2016: The people's guide, South African Cities Network, Johannesburg, viewed 16 March 2018, from http://www. socr.co.za/wp-content/uploads/2016/07/SoCR16-Peoples-Guide-web.pdf

Siyongwana, P.Q. \& Heijne, D., 2014, 'Urban insecurities and spaces of fear in a South African Township: Case study in KwaZakhele, Port Elizabeth', in N. Kotze, R. Donaldson \& G. Visser (eds.), Life in a changing urban landscape: Proceedings of the IGU Urban Geography Commission (Urban challenges in a complex world), pp. 129-140, University of Johannesburg, Johannesburg, viewed 22 March 2018 from https://www.unil.ch/igu-urban/files/live/sites/igu-urban/files/Life $\% 20$ in $\% 20 a \% 20$ changing $\% 20$ urban $\% 20$ space.pdf

Statistics South Africa, 2017, Poverty trends in South Africa: An examination of absolute poverty between 2006 and 2015 (No. 03-10-06), Statistics South Africa, Pretoria, viewed n.d., from http://www.statssa.gov.za/?page_id=1854

Trokan, J., 1997, 'Models of theological reflection: Theory and praxis', Journal of Catholic Education 1(2), 144-158.

Turok, I. \& Borel-Saladin, J., 2018, 'The theory and reality of urban slums: Pathwaysout-of-poverty or cul-de-sacs?', Urban Studies 55(4), 767-789. https://doi. org/10.1177/0042098016671109

Vellem, V.S., 2017, 'Un-thinking the West: The spirit of doing black theology of liberation in decolonial times', HTS Teologiese Studies/Theological Studies 73(3), 1-9. https://doi.org/10.4102/hts.v73i3.4737

Wenger-Trayner, E. \& Wenger-Trayner, B., 2015, Communities of practice: A brief introduction, pp. 1-8, viewed 31 August 2017, from http://wenger-trayner.com/wpcontent/uploads/2015/04/07-Brief-introduction-to-communities-of-practice.pdf 